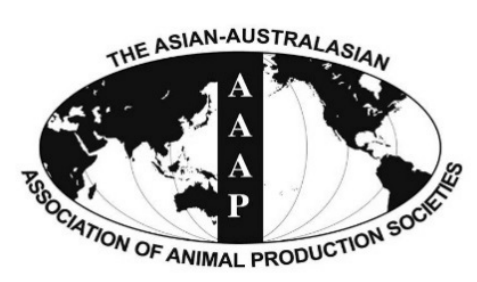

Open Access

Asian Australas. J. Anim. Sci.

Vol. 29, No. 3 : 384-389 March 2016

http://dx.doi.org/10.5713/ajas.15.0141

www.ajas.info

pISSN 1011-2367 elSSN 1976-5517

\title{
Effect of Dietary Beta-Glucan on the Performance of Broilers and the Quality of Broiler Breast Meat
}

\author{
Sun Hee Moon', Inyoung Lee ${ }^{2}$, Xi Feng ${ }^{1}$, Hyun Yong Lee', Jihee Kim¹, and Dong Uk Ahn ${ }^{1,3, *}$ \\ ${ }^{1}$ Department of Animal Science, Iowa State University, Ames, IA 50011, USA
}

\begin{abstract}
A total of 400, one day-old commercial broiler chicks were divided into five diet groups (negative control, positive control group with 55 ppm Zn-bacitracin, 15 ppm $\beta$-glucan, $30 \mathrm{ppm} \beta$-glucan, and $60 \mathrm{ppm} \beta$-glucan) and fed for six weeks. Ten broilers were allotted to each of 40 floor pens. Eight floor pens were randomly assigned to one of the 5 diets. Each diet was fed to the broilers for 6 weeks with free access to water and diet. The survival rate, growth rate, feed efficiency, and feed conversion rate of the broilers were calculated. At the end of the feeding trial, the birds were slaughtered, breast muscles deboned, and quality parameters of the breast meat during storage were determined. The high level of dietary $\beta$-glucan $(60 \mathrm{ppm})$ showed better feed conversion ratio and survival rate than the negative control. The survival rate of $60 \mathrm{ppm} \beta$-glucan-treated group was the same as that of the antibiotic-treated group, which showed the highest survival rate among the treatments. There was no significant difference in carcass yield, water holding capacity, $\mathrm{pH}$, color, and 2-thiobarbituric acid reactive substances values of chicken breast meat among the 5 treatment groups. Supplementation of 60 ppm $\beta$-glucan to broiler diet improved the survival rate and feed conversion rate of broilers to the same level as $55 \mathrm{ppm} \mathrm{Zn}$-bacitracin group. The result indicated that use of $\beta$-glucan $(60 \mathrm{ppm})$ can be a potential alternative to antibiotics to improve the survival and performance of broilers. However, dietary $\beta$-glucan showed no effects on the quality parameters of chicken breast meat. (Key Words: $\beta$ Glucan, Broiler, Growth Performance, Physicochemical Properties)
\end{abstract}

\section{INTRODUCTION}

$\beta-1,3-$ Glucan is a functional polymer consisting of glucose with $\beta-1,3$ linkage and can be isolated from various sources, including grains, mushrooms and bacteria. $\beta-1,3-$ Glucan is known to enhance immunity and bioactivity by promoting secretion of cytokines, activating macrophages, natural killer cells and neutrophils, and have antitumor, antibacterial and antiviral effects (Brown and Gordon, 2005). $\beta$-Glucan also functions as an adjuvant for monoclonal antibody immunotheraphy because it can induce cellular cytotoxicity by recruiting tumoricidal granulocytes as killer cells. $\beta-1,3-$ Glucan is known to increase antibody production by activating the $\mathrm{B}$ cells, has a

\footnotetext{
* Corresponding Author: Dong Uk Ahn. Tel: +1-515-294-6595, Fax: +1-515-294-9143, E-mail: duahn@iastate.edu

${ }^{2}$ Naturence Co., Ltd., Sejong 339-824, Korea.

3 Department of Animal Science and Technology, Sunchon National University, Sunchon 540-742, Korea.

Submitted Feb. 17, 2015; Revised Apr. 28, 2015; Accepted Jun. 17, 2015
}

complementing function in $\mathrm{mAB}$-mediated cancer immunology, and activates the secretion of IL-1, IL-2, TNF- $\alpha$. Therefore, $\beta$-glucan can stimulate the cell-mediated immune reactions, which activates the macrophage, NK cell, and cytotoxic T cell (Bohn and BeMiller, 1995; Vetvicka et al., 2007; Chen et al., 2008). As a result, $\beta$-1,3-glucan can enhance the resistance against infection of microorganisms and virus by improving i) non-specific immunity, which may protect animals against infection, ii) host defense mechanism, and iii) growth rate and reduce mortality. Thus, $\beta$-glucan may be used as a replacement for dietary antibiotics in animal feeds.

Beta Polo, mainly composed of $\beta-1,3$-glucan, is a natural feed additive for poultry. Beta-Polo stimulates immune system and improves host defense mechanism, consequently reducing mortality and enhancing growth (Guo et al., 2003). The quality of meat is significantly influenced by the degree of stresses in animals during growing, transportation, pre-slaughter handling and processing. Therefore, dietary $\beta-1,3$-glucan can have 
significant impact to the quality of meat because it can reduce oxidative stress in birds during growing periods. However, few literature is available in the area.

The objectives of this study were to determine i) the effects of dietary $\beta$-glucan on the survival rate, growth rate, feed efficiency, and feed conversion rate of broilers, and ii) the effects of dietary $\beta$-glucan on the carcass yield, and color, $\mathrm{pH}$, water holding capacity, composition and storage stability of broiler breast meat.

\section{MATERIALS AND METHODS}

\section{Experimental design and diets}

The study was approved by the Institutional Animal Care and Use Committee at Iowa State University (Approval \# 2-12-7313-G). Four hundred, one-day-old commercial broiler chicks were divided into five dietary groups (eight replications $\times 10$ birds each replication) and fed the following diets for six weeks. NC was the negative control group (basal diet, antibiotics-free); PC, the positive control group (55 ppm Zn-bacitracin, approved for broilers and commonly used); 15 BG, 15 ppm $\beta$-glucan; 30 BG, 30 ppm $\beta$-glucan; and $60 \mathrm{BG}, 60 \mathrm{ppm} \beta$-glucan. The $\beta$-glucan product containing 25\% 1,3- $\beta$-glucan was obtained from Naturence Co., Ltd. (Sejong, Korea) and used to formulate the BG treatments.

All five diets were prepared on corn-soybean basal diet, which met or exceed the NRC requirements (NRC, 1994) for birds during the trial. The formula and chemical composition of the basal diets are shown in Table 1. Crude protein, metabolizable energy, $\mathrm{Ca}, \mathrm{P}$, lysine and methionine levels in the four diets were adjusted to the same levels. Ten broilers were allotted to each of 40 floor pens (experimental units), weighed, and wing banded. Eight floor pens were randomly assigned to one of the five experimental diets with different amounts of 1,3- $\beta$-glucan. Each of the dietary treatment was fed to the respective broiler groups for six weeks. Broilers had free access to water and diet. The growth and feed consumption of broilers were measured weekly during the feeding trial. At the end of the feeding trial, survival rate, feed consumption, and feed conversion rate were calculated.

\section{Slaughtering}

At the end of the feeding trial, half of the birds (200) were slaughtered in the Meat Lab at Iowa State University following USDA guidelines (Brant et al., 1982) and carcass weight were obtained $24 \mathrm{~h}$ after slaughter. Breast muscles were deboned from the carcasses the next day and used to measure color, water holding capacity, cooking loss, ultimate $\mathrm{pH}$, and storage stability.
Table 1. Composition of the basal (control) diet (\%)

\begin{tabular}{|c|c|c|c|}
\hline Items & $\begin{array}{c}\text { Starter } \\
(1 \text { to } 14 \mathrm{~d})\end{array}$ & $\begin{array}{c}\text { Grower } \\
\text { (14 to } 28 \mathrm{~d})\end{array}$ & $\begin{array}{l}\text { Finisher } \\
\text { (14 to } 42 \mathrm{~d} \text { ) }\end{array}$ \\
\hline \multicolumn{4}{|l|}{ Ingredient } \\
\hline Corn & 56.3 & 60.02 & 67.87 \\
\hline DDGS & 5 & 5 & 0 \\
\hline Meat/bone meal & 3 & 3 & 3 \\
\hline Soybean meal 48 & 31.3 & 26.71 & 24.02 \\
\hline Soy oil & 1.12 & 2.16 & 2.52 \\
\hline Salt & 0.36 & 0.36 & 0.28 \\
\hline DL methionine & 0.27 & 0.24 & 0.19 \\
\hline Threonine & 0 & 0.01 & 0 \\
\hline Bio-Lys & 0.27 & 0.31 & 0.22 \\
\hline Limestone & 0.69 & 0.74 & 0.74 \\
\hline Dicalcium Phos & 0.96 & 0.72 & 0.57 \\
\hline Choline chloride 60 & 0.1 & 0.1 & 0.1 \\
\hline Vitamin premix $^{1}$ & 0.63 & 0.63 & 0.5 \\
\hline \multicolumn{4}{|l|}{ Calculated values } \\
\hline Crude protein $(\%)$ & 22.95 & 21.08 & 18.99 \\
\hline Poult (ME kcal/kg) & 3,000 & 3,100 & 3,200 \\
\hline Calcium (\%) & 0.9 & 0.85 & 0.8 \\
\hline Phos (\%) & 0.74 & 0.67 & 0.61 \\
\hline Avail Phos (\%) & 0.45 & 0.4 & 0.35 \\
\hline Fat $(\%)$ & 4.44 & 5.52 & 5.7 \\
\hline Fibre $(\%)$ & 2.83 & 2.76 & 2.51 \\
\hline Met (\%) & 0.63 & 0.58 & 0.49 \\
\hline Cys (\%) & 0.37 & 0.34 & 0.32 \\
\hline Me+Cys (\%) & 1 & 0.92 & 0.81 \\
\hline Lys (\%) & 1.33 & 1.21 & 1.07 \\
\hline His $(\%)$ & 0.6 & 0.55 & 0.5 \\
\hline Tryp (\%) & 0.25 & 0.22 & 0.2 \\
\hline Thr (\%) & 0.86 & 0.8 & 0.71 \\
\hline $\operatorname{Arg}(\%)$ & 1.5 & 1.35 & 1.23 \\
\hline Iso (\%) & 0.95 & 0.86 & 0.76 \\
\hline Leu $(\%)$ & 1.96 & 1.83 & 1.69 \\
\hline Phe $(\%)$ & 1.09 & 1 & 0.9 \\
\hline Tyr (\%) & 0.8 & 0.73 & 0.67 \\
\hline Val (\%) & 1.07 & 0.98 & 0.88 \\
\hline Gly (\%) & 1.04 & 0.97 & 0.91 \\
\hline $\operatorname{Ser}(\%)$ & 1.07 & 0.98 & 0.88 \\
\hline Phe+Tyr (\%) & 1.89 & 1.73 & 1.57 \\
\hline Phytate P (\%) & 0.22 & 0.21 & 0.2 \\
\hline $\mathrm{Na}(\%)$ & 0.19 & 0.19 & 0.15 \\
\hline $\mathrm{Cl}(\%)$ & 0.29 & 0.29 & 0.23 \\
\hline $\mathrm{K}(\%)$ & 0.91 & 0.82 & 0.75 \\
\hline Linoleic acid (\%) & 1.69 & 2.16 & 2.34 \\
\hline $\mathrm{Na}+\mathrm{K}-\mathrm{Cl}$ & 233.52 & 211.54 & 192.7 \\
\hline
\end{tabular}

DDGS, distillers dried grains with soluble; ME, metabolizable energy.

${ }^{1}$ Vitamin premix; $0.2 \mathrm{ppm}$ Selenium, 6,608 IU vitamin A, 2,203 ICU vitamin $\mathrm{D}_{3}, 14 \mathrm{IU}$ vitamin $\mathrm{E}, 0.88 \mathrm{mg}$ menadione, $9.35 \mu \mathrm{g}$ vitamin $\mathrm{B}_{12}$, $33 \mu \mathrm{g}$ biotin, $358 \mathrm{mg}$ choline, $1.1 \mathrm{mg}$ folic acid, $33 \mathrm{mg}$ niacin, $8.8 \mathrm{mg}$ pantothenic acid, $0.88 \mathrm{mg}$ pyridoxine, $4.4 \mathrm{mg}$ riboflavin, $1.1 \mathrm{mg}$ thiamine) $/ \mathrm{kg}$ basal diet. The diets were formulated to be iso-caloric based on energy values for feed ingredients published by the National Research Council, and were formulated on a total amino acid basis for methionine, threonine, and lysine. 


\section{Growth performance}

Body weight and feed intake per cage were recorded, and feed conversion rate was calculated based on feed intake divided by body weight gain throughout the experiment after adjusting mortality.

\section{Physicochemical properties of broiler breast meat}

The analyses of the color, $\mathrm{pH}$ and water holding capacity in the broiler meat samples were conducted on one of the two breast muscles obtained from each animal by random selection.

Color measurements: Color was measured using a Labscan spectrophotometer (Hunter Associated Labs Inc., Reston, VA, USA) (AMSA, 1991) that had been calibrated against white and black reference tiles covered with the same film as those used for meat samples. Commission Internationale de l'Eclairage (CIE) L* (lightness), a* (redness), and $\mathrm{b}^{*}$ (yellowness) values were obtained using illuminant A (light source). Area view and port size were 0.64 and $1.02 \mathrm{~cm}$, respectively. An average value from two random locations of the meat surface was used for statistical analysis.

$p H$ : The $\mathrm{pH}$ values of the breast muscle were measured in duplicate with a $\mathrm{pH}$ meter. About $10 \mathrm{~g}$ of the sample was minced to small pieces and homogenized with $90 \mathrm{~mL}$ of distilled water for $60 \mathrm{~s}$ using a Polytron homogenizer. The $\mathrm{pH}$ values were measured immediately after the homogenization.

Water holding capacity: Water-holding capacity was measured using the centrifugation method of Bertram et al. (2001). Breast samples were cut parallel to the muscle fiber direction, which is about $2.0 \mathrm{~cm}$ long and $0.5 \mathrm{~cm} \times 0.2 \mathrm{~cm}$ in cross-sectional area. The samples were weighed and placed in test tubes with a filter paper (Whatman No. 1) cushion. The tubes were sealed with parafilm and then centrifuged at $400 \times \mathrm{g}$ at $4^{\circ} \mathrm{C}$ for $60 \mathrm{~min}$. After centrifugation, the samples were weighed again. Water holding capacity was calculated as the percentage difference in weight before and after centrifugation. Eight replications were conducted for each treatment.

Lipid oxidation (2-thiobarbituric acid reactive substances, TBARS): Lipid oxidation of breast meat was assessed on the basis of malondialdehyde (MDA) formed during the refrigerated storage. Lipid oxidation was determined using a 2-thiobarbituric acid reactive substances (TBARS) method (Ahn et al., 1998). Meat sample (5 g) was placed in a $50-\mathrm{mL}$ test tube and homogenized with $15 \mathrm{~mL}$ deionized distilled water for $15 \mathrm{~s}$ at high speed (Type PT 10/35; Brinkman Instrument Inc., Westbury, NY, USA). The meat homogenate $(1 \mathrm{~mL})$ was transferred to a disposable test tube, and butylated hydroxytoluene $(7.2 \%, 50 \mu \mathrm{L})$ and thiobarbituric acid (TBA)/trichloroacetic acid (TCA) solution $(2 \mathrm{~mL})$ were added. The sample was mixed using a vortex mixer, and then incubated in a $90^{\circ} \mathrm{C}$ water bath for 15 min to develop color. After cooling, the samples were centrifuged at $3,000 \times \mathrm{g}$ for $15 \mathrm{~min}$ at $4^{\circ} \mathrm{C}$. The absorbance of the resulting upper layer was read at $531 \mathrm{~nm}$ against a blank prepared with $1 \mathrm{~mL}$ deionized distilled water and 2 $\mathrm{mL}$ TBA/TCA solution. The amounts of TBARS were expressed as mg of MDA per $\mathrm{kg}$ of meat.

\section{Statistical analysis}

Experiments were carried out in eight replications, and the results represent the average values of the replications. Samples were compared by One way analysis of variance followed by Tukey's multiple comparison test (SPSS version 18, SPSS Inc., Chicago, Illinois). Statistical significance was set at $\mathrm{p}<0.05$.

\section{RESULTS AND DISCUSSION}

\section{Growth performance}

The feed consumption and body weight gain of broiler

Table 2. Effect of $\beta$-glucan on the feed consumption and body weight gain of broiler chickens

\begin{tabular}{|c|c|c|c|c|c|c|c|}
\hline Items & $1 \mathrm{wk}$ & $2 \mathrm{wk}$ & $3 \mathrm{wk}$ & $4 \mathrm{wk}$ & $5 \mathrm{wk}$ & $6 \mathrm{wk}$ & Total \\
\hline \multicolumn{8}{|c|}{ Feed consumed (kg/pen/week) } \\
\hline $\mathrm{NC}$ & $1.33 \pm 0.12$ & $3.63 \pm 0.29$ & $6.51 \pm 0.37$ & $9.00 \pm 0.51$ & $10.20 \pm 0.46$ & $9.67 \pm 1.06$ & $40.34 \pm 2.81$ \\
\hline $\mathrm{PC}$ & $1.49 \pm 0.11$ & $3.80 \pm 0.20$ & $6.78 \pm 0.38$ & $8.83 \pm 0.58$ & $10.00 \pm 0.63$ & $9.65 \pm 1.09$ & $40.55 \pm 3.00$ \\
\hline $15 \mathrm{BG}$ & $1.44 \pm 0.16$ & $3.81 \pm 0.18$ & $6.77 \pm 0.39$ & $9.15 \pm 0.51$ & $10.01 \pm 0.39$ & $9.33 \pm 0.67$ & $40.51 \pm 2.29$ \\
\hline $30 \mathrm{BG}$ & $1.45 \pm 0.13$ & $3.83 \pm 0.18$ & $6.92 \pm 0.22$ & $9.21 \pm 0.39$ & $10.17 \pm 0.29$ & $9.21 \pm 0.52$ & $40.79 \pm 1.73$ \\
\hline $60 \mathrm{BG}$ & $1.34 \pm 0.11$ & $3.63 \pm 0.25$ & $6.32 \pm 0.45$ & $8.56 \pm 0.68$ & $9.66 \pm 0.78$ & $9.25 \pm 0.87$ & $38.76 \pm 3.15$ \\
\hline \multicolumn{8}{|c|}{ Body weight gain (kg/pen/week) } \\
\hline $\mathrm{NC}$ & $1.50 \pm 0.14$ & $2.58 \pm 0.31$ & $4.28 \pm 0.48$ & $5.38 \pm 0.51$ & $5.11 \pm 0.53$ & $4.18 \pm 0.89$ & $23.03 \pm 0.48$ \\
\hline $\mathrm{PC}$ & $1.58 \pm 0.07$ & $2.71 \pm 0.17$ & $4.58 \pm 0.17$ & $5.40 \pm 0.49$ & $5.39 \pm 0.23$ & $4.36 \pm 0.63$ & $24.04 \pm 0.29$ \\
\hline $15 \mathrm{BG}$ & $1.49 \pm 0.09$ & $2.61 \pm 0.14$ & $4.40 \pm 0.29$ & $5.38 \pm 0.40$ & $4.73 \pm 0.78$ & $4.37 \pm 0.16$ & $22.98 \pm 0.31$ \\
\hline $30 \mathrm{BG}$ & $1.52 \pm 0.11$ & $2.55 \pm 0.23$ & $4.33 \pm 0.28$ & $5.36 \pm 0.25$ & $5.11 \pm 0.35$ & $4.45 \pm 0.81$ & $23.36 \pm 0.34$ \\
\hline $60 \mathrm{BG}$ & $1.53 \pm 0.08$ & $2.66 \pm 0.14$ & $4.54 \pm 0.36$ & $5.60 \pm 0.41$ & $5.15 \pm 0.26$ & $4.26 \pm 0.50$ & $23.74 \pm 0.29$ \\
\hline
\end{tabular}

Values are mean \pm standard deviation of each treatment group. $\mathrm{n}=8$.

$\mathrm{NC}$, negative control; PC, positive control (adding Zinc bacitracin); $15 \mathrm{BG}$, adding 15 ppm $\beta$-glucan (6 g/100 kg diet); $30 \mathrm{BG}$, adding 30 ppm $\beta$-glucan (12 g/100 kg diet); $60 \mathrm{BG}$, adding 60 ppm $\beta$-glucan $(24 \mathrm{~g} / 100 \mathrm{~kg}$ diet). 
chicks are shown in Table 2. No differences in weekly feed consumption and body weight gain among dietary treatment groups were found during the 6-week feeding trial $(\mathrm{p}>0.05)$. The feed consumption of birds with PC, 15 BG and 30 BG were not different from that of the control (NC). However, high level of beta glucan (60 ppm, 60 BG) treatment showed numerically lower feed consumption than other treatments. In agreement with our results, other studies observed no effects of $\beta$-glucan on growth performance (Morales-Lopez et al., 2009; Cox et al., 2010). Hahn et al. (2006) also reported that $\beta$-glucan did not show any effects on average daily feed intake and gain to feed ratio $(\mathrm{G}: \mathrm{F}$ ratio) as the $\beta$-glucan level of the $\operatorname{diet}(0,0.1,0.2,0.3$, and $0.4 \mathrm{~g} / \mathrm{kg}$ ) increased in weanling pigs.

Table 3 showed the feed conversion rate of chickens fed with diets containing various concentrations of $\beta$-glucan. There was no significant difference in feed conversion rate among the five treatment groups. However, the high-level $\beta$-glucan treatment (60 ppm, $60 \mathrm{BG}$ ) showed numerically better feed conversion rate than the negative control (Table 3 ). In fact, $60 \mathrm{ppm} \beta$-glucan group showed better feed conversion rate than that of $55 \mathrm{ppm}$ bacitracin group (PC), which is encouraging. Mao et al. (2005) reported that dietary supplement of 1,3-1,6- $\beta$-glucans from Chinese herb did not show the improvement of performances. Also, 1,31,6,- $\beta$-glucan extracted from Paenibacillus polymyxa showed no significant improvement in growth performances (Hwang et al., 2008). These findings suggested that $\beta$-glucans from various sources were able to cause divergent responses in relation with their structures and sources. All $\beta$-glucan treatment groups (15 BG - 60 BG)
Table 3. Effect of $\beta$-glucan on the feed conversion rate and survival rate of broiler chickens

\begin{tabular}{lcc}
\hline Group & Feed conversion rate & Survival rate (\%) \\
\hline NC & $1.752 \pm 0.170$ & 93.75 \\
PC & $1.687 \pm 0.101$ & 98.75 \\
15 BG & $1.763 \pm 0.188$ & 96.25 \\
$30 \mathrm{BG}$ & $1.746 \pm 0.096$ & 96.25 \\
$60 \mathrm{BG}$ & $1.633 \pm 0.218$ & 98.75 \\
\hline
\end{tabular}

Values are mean \pm standard deviation of each treatment group. $\mathrm{n}=8$.

NC, negative control; PC, positive control (adding Zinc bacitracin); 15 BG; adding $15 \mathrm{ppm} \beta$-glucan; $30 \mathrm{BG}$, adding $30 \mathrm{ppm} \beta$-glucan; $60 \mathrm{BG}$, adding $60 \mathrm{ppm} \beta$-glucan.

showed numerically higher survival rate than the control, and the survival rate of $60 \mathrm{ppm} \beta$-glucan-treated group (60 BG) was the same as that of the antibiotic-treated group (PC), which showed the highest survival rate among the treatments (Table 3). Our results suggested that $>60 \mathrm{ppm}$ of dietary $\beta$-glucan can have a possibility of replacing antibiotics to improve survival rate and promote growth of broilers.

\section{Physicochemical properties of breast meat}

Color is the most important perceivable quality in meat products in terms of consumer acceptance. Many factors have been shown to affect poultry meat color, such as bird sex, age, strain, method of processing, exogenous chemicals, cooking method irradiation, and freezing (Froning, 1995). Table 4 shows the color $\mathrm{L}^{*}$-values (lightness), $\mathrm{a}^{*}$-values (redness), and $\mathrm{b}^{*}$-values (yellowness) of chicken breast meat from chickens fed with various concentrations of $\beta$ glucan. The lightness of chicken breast meat decreased

Table 4. Dietary effects of $\beta$-glucan on the meat color quality in broiler chickens

\begin{tabular}{|c|c|c|c|c|c|}
\hline & & $0 \mathrm{~d}$ & $1 \mathrm{~d}$ & $3 d$ & $7 \mathrm{~d}$ \\
\hline \multirow[t]{5}{*}{$\mathrm{L}^{*}$} & $\mathrm{NC}$ & $60.87 \pm 2.22^{\text {ay }}$ & $59.98 \pm 3.17^{\text {ay }}$ & $59.75 \pm 2.25^{\text {ay }}$ & $57.49 \pm 2.19^{\mathrm{ax}}$ \\
\hline & $\mathrm{PC}$ & $61.45 \pm 1.65^{\mathrm{az}}$ & $59.27 \pm 1.39^{\text {ay }}$ & $59.07 \pm 2.77^{\text {ay }}$ & $55.61 \pm 2.73^{\mathrm{ax}}$ \\
\hline & $15 \mathrm{BG}$ & $60.76 \pm 2.39^{\mathrm{az}}$ & $58.16 \pm 2.08^{\mathrm{axy}}$ & $57.49 \pm 1.35^{\mathrm{ax}}$ & $59.64 \pm 1.87^{\text {byz }}$ \\
\hline & $30 \mathrm{BG}$ & $59.54 \pm 2.30^{\text {ax }}$ & $58.64 \pm 2.19^{\mathrm{ax}}$ & $57.76 \pm 3.36^{\mathrm{ax}}$ & $57.38 \pm 2.66^{\mathrm{ax}}$ \\
\hline & $60 \mathrm{BG}$ & $61.33 \pm 2.54^{\text {ay }}$ & $60.34 \pm 3.90^{\text {axy }}$ & $57.86 \pm 2.57^{\mathrm{ax}}$ & $57.90 \pm 2.81^{\mathrm{ax}}$ \\
\hline \multirow[t]{5}{*}{$a^{*}$} & $\mathrm{NC}$ & $7.50 \pm 1.70^{\mathrm{ax}}$ & $7.14 \pm 1.52^{\mathrm{ax}}$ & $7.05 \pm 0.97^{\mathrm{ax}}$ & $8.43 \pm 2.01^{\mathrm{ax}}$ \\
\hline & $\mathrm{PC}$ & $7.93 \pm 1.55^{\mathrm{ax}}$ & $8.27 \pm 1.22^{\text {axy }}$ & $7.48 \pm 1.37^{\mathrm{abx}}$ & $9.29 \pm 1.44^{\text {ay }}$ \\
\hline & $15 \mathrm{BG}$ & $7.83 \pm 1.14^{\mathrm{ax}}$ & $8.44 \pm 1.54^{\mathrm{ax}}$ & $7.54 \pm 2.06^{\mathrm{abx}}$ & $8.07 \pm 1.37^{\mathrm{ax}}$ \\
\hline & $30 \mathrm{BG}$ & $7.73 \pm 1.60^{\text {ax }}$ & $8.31 \pm 0.98^{\mathrm{ax}}$ & $8.86 \pm 1.64^{\mathrm{bx}}$ & $8.44 \pm 2.11^{\mathrm{ax}}$ \\
\hline & $60 \mathrm{BG}$ & $8.72 \pm 1.45^{\mathrm{ax}}$ & $8.28 \pm 1.33^{\text {ax }}$ & $8.54 \pm 1.53^{b x}$ & $7.89 \pm 1.39^{\mathrm{ax}}$ \\
\hline \multirow[t]{5}{*}{$\mathrm{b}^{*}$} & $\mathrm{NC}$ & $12.14 \pm 1.72^{\mathrm{ax}}$ & $11.67 \pm 3.08^{\mathrm{ax}}$ & $10.75 \pm 0.93^{\mathrm{ax}}$ & $13.74 \pm 2.79^{\text {ay }}$ \\
\hline & $\mathrm{PC}$ & $13.32 \pm 2.68^{\mathrm{bx}}$ & $12.38 \pm 1.50^{\mathrm{ax}}$ & $12.98 \pm 2.14^{\mathrm{ax}}$ & $13.37 \pm 1.88^{\mathrm{ax}}$ \\
\hline & $15 \mathrm{BG}$ & $12.61 \pm 1.45^{\mathrm{ax}}$ & $12.38 \pm 2.32^{\mathrm{ax}}$ & $11.80 \pm 3.20^{\mathrm{ax}}$ & $14.09 \pm 3.11^{\mathrm{ax}}$ \\
\hline & $30 \mathrm{BG}$ & $11.87 \pm 1.42^{\mathrm{ax}}$ & $11.85 \pm 2.16^{\mathrm{ax}}$ & $12.81 \pm 3.24^{\mathrm{ax}}$ & $13.95 \pm 3.71^{\mathrm{ax}}$ \\
\hline & $60 \mathrm{BG}$ & $14.48 \pm 1.11^{\text {by }}$ & $12.17 \pm 2.65^{\mathrm{ax}}$ & $12.59 \pm 1.87^{\mathrm{ax}}$ & $14.34 \pm 1.71^{\text {ay }}$ \\
\hline
\end{tabular}

Values are mean \pm standard deviation of each treatment group. $\mathrm{n}=8$.

NC, negative control; PC, positive control (adding Zinc bacitracin); 15 BG, adding 15 ppm $\beta$-glucan; 30 BG, adding 30 ppm $\beta$-glucan; 60 BG, adding 60 ppm $\beta$-glucan.

a-c Statistically significant differences $(\mathrm{p}<0.05)$ between column.

${ }^{\mathrm{x}-\mathrm{z}}$ Statistically significant differences $(\mathrm{p}<0.05)$ between incubation row. 
significantly during storage due to pigments oxidation, but no significant difference among 5 treatment groups was found. Redness and yellowness also were not influenced by the dietary treatments and storage even though there were some ups and downs in the values. This result indicated that dietary Zinc bacitracin and $\beta$-glucan had no effects on the color values of chicken breast meat. Other research agreed that $\beta$-glucan $(13.45 \%$ Nutrim-10 which contain $10 \% \beta$ glucan) did not affect the color characteristics in beef patties (Pinero et al., 2008).

Meat $\mathrm{pH}$ is known to influence parameters related to meat quality including color, tenderness, flavor and shelflife. The $\mathrm{pH}$ of the chicken breast with various concentrations of $\beta$-glucan is shown in Table 5. The $\mathrm{pH}$ of chicken breast meat was not significantly different among the dietary treatments groups even though there were some decrease in $\mathrm{pH}$ after 1 day of storage in all groups $(\mathrm{p}>0.05)$. Water holding capacity (WHC) of the chicken breast from chickens fed with various concentrations of $\beta$-glucan is shown in Table 5. The water holding capacity of the chicken breast meat was not significantly different among the treatment groups and during storage $(\mathrm{p}>0.05)$. There were very large variations in WHC among the breast muscles even from the same dietary treatment group. No difference in carcass yield among the treatment groups was also detected (data not shown).

Lipid oxidation of the raw chicken breast meat during storage is shown in Table 6. The TBARS values of chicken breast were not differ significantly among the treatment groups. The TBARS values of chicken breast meat during the 7-day storage time differ significantly: 3d-stored samples had the lowest and 7 day-stored samples had the highest values. However, the difference does not have much

Table 5. Dietary effects of $\beta$-glucan on the $\mathrm{pH}$ values and the water holding capacity in broiler chickens

\begin{tabular}{|c|c|c|c|c|}
\hline Items & $0 \mathrm{~d}$ & $1 \mathrm{~d}$ & $3 \mathrm{~d}$ & $7 \mathrm{~d}$ \\
\hline \multicolumn{5}{|l|}{$\mathrm{pH}$} \\
\hline $\mathrm{NC}$ & $6.30 \pm 0.14^{\mathrm{bx}}$ & $6.22 \pm 0.17^{\text {ax }}$ & $6.20 \pm 0.12^{\mathrm{ax}}$ & $6.29 \pm 0.09^{\mathrm{ax}}$ \\
\hline $\mathrm{PC}$ & $6.12 \pm 0.10^{\mathrm{ax}}$ & $6.24 \pm 0.08^{\mathrm{ax}}$ & $6.27 \pm 0.07^{\mathrm{ax}}$ & $6.18 \pm 0.09^{\mathrm{ax}}$ \\
\hline $15 \mathrm{BG}$ & $6.42 \pm 0.09^{\mathrm{cy}}$ & $6.23 \pm 0.10^{\mathrm{ax}}$ & $6.22 \pm 0.09^{\mathrm{ax}}$ & $6.24 \pm 0.11^{\mathrm{ax}}$ \\
\hline $30 \mathrm{BG}$ & $6.48 \pm 0.12^{\mathrm{cy}}$ & $6.21 \pm 0.15^{\mathrm{ax}}$ & $6.22 \pm 0.14^{\mathrm{ax}}$ & $6.23 \pm 0.10^{\mathrm{ax}}$ \\
\hline $60 \mathrm{BG}$ & $6.12 \pm 0.14^{\mathrm{ax}}$ & $6.18 \pm 0.13^{\mathrm{ax}}$ & $6.20 \pm 0.09^{\mathrm{ax}}$ & $6.21 \pm 0.07^{\mathrm{ax}}$ \\
\hline \multicolumn{5}{|c|}{ Water holding capacity } \\
\hline $\mathrm{NC}$ & $83.66 \pm 2.16^{\mathrm{ax}}$ & $82.91 \pm 4.47^{\mathrm{ax}}$ & $81.76 \pm 4.78^{\mathrm{ax}}$ & $81.51 \pm 5.47^{\mathrm{ax}}$ \\
\hline $\mathrm{PC}$ & $83.18 \pm 2.55^{\mathrm{ax}}$ & $81.90 \pm 3.02^{\mathrm{ax}}$ & $85.06 \pm 5.12^{\mathrm{ax}}$ & $81.18 \pm 6.22^{\mathrm{ax}}$ \\
\hline $15 \mathrm{BG}$ & $84.49 \pm 2.43^{\text {ay }}$ & $83.59 \pm 6.51^{\text {ay }}$ & $85.38 \pm 5.35^{\text {ay }}$ & $77.09 \pm 6.09^{\mathrm{ax}}$ \\
\hline $30 \mathrm{BG}$ & $82.50 \pm 3.26^{\mathrm{ax}}$ & $82.40 \pm 4.38^{\mathrm{ax}}$ & $82.31 \pm 5.89^{\mathrm{ax}}$ & $79.34 \pm 5.30^{\mathrm{ax}}$ \\
\hline $60 \mathrm{BG}$ & $81.27 \pm 3.25^{\mathrm{ax}}$ & $81.12 \pm 4.39^{\mathrm{ax}}$ & $81.02 \pm 3.28^{\mathrm{ax}}$ & $82.86 \pm 3.06^{\mathrm{ax}}$ \\
\hline \multicolumn{5}{|c|}{$\begin{array}{l}\text { Values are mean } \pm \text { standard deviation of each treatment group. } \mathrm{n}=8 \text {. } \\
\mathrm{NC} \text {, negative control; PC, positive control (adding Zinc bacitracin); } 15 \\
\mathrm{BG} \text {, adding } 15 \mathrm{ppm} \beta \text {-glucan; } 30 \mathrm{BG} \text {, adding } 30 \mathrm{ppm} \beta \text {-glucan; } 60 \mathrm{BG} \text {, } \\
\text { adding } 60 \mathrm{ppm} \beta \text {-glucan. } \\
\text { a-c Statistically significant differences ( }<<0.05 \text { ) between column. } \\
\text { x-z Statistically significant differences }(\mathrm{p}<0.05 \text { ) between row. }\end{array}$} \\
\hline
\end{tabular}

Table 6. Dietary effects of $\beta$-glucan on the lipid oxidation in raw broiler chicken breast meat

\begin{tabular}{llcc}
\hline & $0 \mathrm{~d}$ & $3 \mathrm{~d}$ & $7 \mathrm{~d}$ \\
\hline $\mathrm{NC}$ & $0.16 \pm 0.07^{\text {ay }}$ & $0.09 \pm 0.01^{\text {ax }}$ & $0.20 \pm 0.03^{\text {ay }}$ \\
$\mathrm{PC}$ & $0.17 \pm 0.04^{\text {axy }}$ & $0.14 \pm 0.16^{\text {ax }}$ & $0.26 \pm 0.03^{\text {ay }}$ \\
$15 \mathrm{BG}$ & $0.14 \pm 0.04^{\text {ay }}$ & $0.08 \pm 0.02^{\text {ax }}$ & $0.21 \pm 0.04^{\text {az }}$ \\
$30 \mathrm{BG}$ & $0.15 \pm 0.04^{\text {ax }}$ & $0.11 \pm 0.01^{\text {ax }}$ & $0.22 \pm 0.06^{\text {ay }}$ \\
$60 \mathrm{BG}$ & $0.15 \pm 0.04^{\text {ay }}$ & $0.08 \pm 0.01^{\text {ax }}$ & $0.21 \pm 0.03^{\text {az }}$ \\
\hline
\end{tabular}

Values are mean \pm standard deviation of each treatment group. $n=8$. NC, negative control; PC, positive control (adding Zinc bacitracin); 15 $\mathrm{BG}$, adding $15 \mathrm{ppm} \beta$-glucan; $30 \mathrm{BG}$, adding $30 \mathrm{ppm} \beta$-glucan; $60 \mathrm{BG}$, adding 60 ppm $\beta$-glucan.

${ }^{\text {a-c }}$ Statistically significant differences $(\mathrm{p}<0.05)$ between column.

${ }^{x-z}$ Statistically significant differences $(\mathrm{p}<0.05)$ between row.

practical meaning to the meat quality at these low values. Dileep et al. (2011) demonstrated that $\beta$-glucan had radical scavenging ability while trying to use as hemopoietic stimulant/radioprotectant, and Thondre et al. (2011) reported that the free radical scavenging ability of $\beta$-glucan is due to the presence of polyphenol and antioxidant content in the commercial $\beta$-glucan sample. All the TBARS values of raw chicken breast meat are very low, indicating that raw chicken breasts are highly resistant to oxidative changes during storage. Although dietary $\beta$-glucan showed some effects to broiler performances, but did not show significant effect to the meat quality.

\section{CONCLUSION}

Dietary supplementation with $\beta$-glucan improved survival rate and feed efficiency. In general, these responses indicated that $\beta$-glucan can be a potential alternative to antibiotic growth promoter in order to improve growth performance. However, dietary $\beta$-glucan showed no effects on the quality parameters of chicken breast meat.

\section{CONFLICT OF INTEREST}

We certify that there is no conflict of interest with any financial organization regarding the material discussed in the manuscript.

\section{ACKNOWLEDGMENTS}

This study was supported jointly by Naturence Co., Ltd., Korea and the Next-Generation BioGreen 21 Program (No. PJ00964305), Rural Development Administration, Republic of Korea.

\section{REFERENCES}

Ahn, D. U., D. G. Olson, C. Jo, X. Chen, C. Wu, and J. I. Lee. 1998. Effect of muscle type, packaging, and irradiation on 
lipid oxidation, volatile production, and color in raw pork patties. Meat Sci. 49:27-39.

AMSA (American Meat Science Association). 1991. Guidelines for meat color evaluation. In Proceedings of the 44th reciprocal meat conference. National Live Stock and Meat Board, Chicago, IL, USA.

Bertram, H. C., H. J. Andersen, and A. H. Karlsson. 2001. Comparative study of low-field NMR relaxation measurements and two traditional methods in the determination of water holding capacity of pork. Meat Sci. 57:125-132.

Brant, A. W., J. W. Goble, J. A. Hamann, C. J. Wabeck, and R. E. Walters. 1982. Guidelines for establishing and operating broiler processing plants. United States Department of Agriculture, Agricultural Research Service, Agriculture Handbook Number 581.

Brown, G. D. and S. Gordon. 2005. Immune recognition of fungal $\beta-1,3-1,6-$ glucans. Cell. Microbiol. 7:471-479.

Bohn, J. A. and J. N. BeMiller. 1995. (1-3)- $\beta$-D-glucans as biological response modifiers: A review of structure-functional activity relationships. Carbohydr. Polym. 28:3-14.

Chen, K. L., B. C. Weng, M. T. Chang, Y. H. Liao, T. T. Chen, and C. Chu. 2008. Direct enhancement of the phagocytic and bactericidal capability of abdominal macrophage of chicks by ß-1, 3-1, 6-glucan. Poult. Sci. 87:2242-2249.

Cox, C. M., L. H. Stuard, S. Kim, A. P. McElroy, M. R. Bedford, and R. A. Dalloul. 2010. Performance and immune responses to dietary beta-glucan in broiler chicks. Poult. Sci. 89:19241933.

Dipeep, A. O., P. Graham, and B. Mirko. 2011. Effect of different ingredients on color and oxidative characteristics of high pressure processed chicken breast meat with special emphasis on use of $\beta$-glucan as a partial salt replacer. Innov. Food Sci. Emerg. Technol. 12:244-254.

Froning, G. W. 1995. Color of poultry meat. Poult. Avian Biol. Rev. 6: 83-93.
Guo, Y., R. A. Ali, and M. A. Qureshi. 2003. The influence of betaglucan on immune responses in broiler chicks. Immunopharmacol. Immunotoxicol. 25:461-472.

Hahn, T. W., J. D. Lohakara, S. L. Lee, W. K. Moon, and B. J. Chae. 2006. Effects of supplementation of $\beta$-glucans on growth performance, nutrient digestibility, and immunity in weanling pigs. J. Anim. Sci. 84:1422-1428.

Hwang, Y. H., B. K. Park, J. H. Lim, M. S. Kim, I. B. Song, S. C. Park, H. K. Jung, J. H. Hong, and H. I. Yun. 2008. Effects of $\beta$ glucan from Paenibacillus polymyxa and L-theanine on growth performance and immunomodulation in weanling piglets. Asian Australas. J. Anim. Sci. 21:1753-1759.

Mao, X. F., X. S. Piao, C. H. Lai, D. H. Li, J. J. Xing, and B. L. Shi. 2005. Effects of $\beta$-glucan obtained from the Chinese herb astragalus membranaceus and lipopolysaccharide challenge on performance, immunological, adrenal, and somatotropic responses of weanling pigs. J. Anim. Sci. 83:2775-2782.

Morales-Lopez, R., E. Auclair, F. Garcia, E. Esteve-Garcia, and J. Brufau. 2009. Use of yeast cell walls; $\beta-1,3 / 1,6$-glucans; and mannoproteins in broiler chicken diets. Poult. Sci. 88: 601-607.

National Research Council (NRC). 1994. Nutrient requirement for poultry. Ninth revision, National Academy Ptress, Washington, DC, USA.

Pinero, M. P., K. Parra, N. Huerta-Leidenz, A. Moreno, M. Ferrer, S. Araujo, and Y. Barboza. 2008. Effect of oat's soluble fibre ( $\beta$-glucan) as a fat replacer on physical, chemical, microbiological and sensory properties of low-fat beef patties. Meat Sci. 80:675-680.

Thondre, P. S., L. Ryan, and C. J. K. Henry. 2011. Barley $\beta$-glucan extracts as rich sources of polyphenols and antioxidants. Food Chem. 126:72-77.

Vetvicka, V., B. Dvorak, J. Vetvickova, J. Richter, J. Krizan, P. Sima, and J. C. Yvin. 2007. Orally administered marine $(1 \rightarrow 3)-\beta$-d-glucan Phycarine stimulates both humoral and cellular immunity. Int. J. Biol. Macromol. 40:291-298. 